\title{
First report of Fusarium lacertarum causing cladode rot in Nopalea cochenellifera in Brazil
}

\author{
Michele F. Santiago ${ }^{1}$ - Alice M. G. Santos ${ }^{2}$ - Cícero P. Inácio ${ }^{3} \cdot$ Amaro C. Lira Neto $^{4} \cdot$ Tereza C. Assis $^{4} \cdot$ Rejane P. Neves $^{4}$. \\ Vinson P. Doyle ${ }^{5}$. Josiene S. Veloso ${ }^{1} \cdot$ Willie A. S. Vieira ${ }^{1} \cdot$ Marcos P. S Câmara $^{1}$ • Delson Laranjeira ${ }^{1}$
}

Received: 5 July 2018 / Accepted: 11 July 2018 / Published online: 9 August 2018

(C) Società Italiana di Patologia Vegetale (S.I.Pa.V.) 2018

In March 2015, a disease led to death several Cochineal opuntia (Nopalea cochenillifera) plants in Ibimirim, Pernambuco state (Brazil). Soft and greenish necrotic spots appeared on cladodes and at the plant base. Infected cladodes wilted and fell from the plant, leaving the internal woody tissues exposed. Fragments from symptomatic tissues were surface disinfected, plated on potato dextrose agar (PDA), and incubated at $25 \pm$ $2{ }^{\circ} \mathrm{C}$ for seven days. Mycelium on PDA was white, and the bottom of the colony showed brown-orange pigmentation. Chlamydospores on clove leaf agar were solitary and terminal, macroconidia were falcate, $11.6-25.7 \times 1.8-2.3 \mu \mathrm{m}$ in size. Microconidia were not observed. These morphological characteristics tallied with those of Fusarium lacertarum (Leslie and Summerell 2006). The elongation factor- $1 \alpha$ region was sequenced and compared with that of other Fusarium species

Electronic supplementary material The online version of this article (https://doi.org/10.1007/s42161-018-0120-0) contains supplementary material, which is available to authorized users.

Delson Laranjeira

delson.laranjeira@ufrpe.br

1 Departamento de Agronomia, Universidade Federal Rural de Pernambuco, Recife, Brazil

2 Departamento de Agronomia, Universidade Estadual do Piauí, Piauí, Brazil

3 Departamento de Micologia, Universidade Federal de Pernambuco, Recife, Brazil

4 Instituto Agronômico de Pernambuco, Recife, Brazil

5 Department of Plant Pathology and Crop Physiology, Louisiana State University AgCenter, Baton Rouge, Louisiana, USA from Fusarium-ID database, and subsequently in a maximum likelihood phylogenetic analysis including previously published sequences (O'Donnell et al. 2009). Our isolate (URM7639, GenBank accession No. MG029527) was 99\% similar in sequence to Fusarium lacertarum, a member of $F$. incarnatum-equiseti species. The isolate was also nested in a clade containing the ex-type of $F$. lacertarum with $87 \%$ support. Pathogenicity was evaluated by wounding cladodes at three locations and applying mycelial plugs to each wound. Cladodes inoculated with sterile PDA plugs represented the negative control. The same symptoms observed in the field were reproduced only in inoculated cladodes, from which the pathogen was reisolated. F. lacertarum was previously reported in Brazil causing damping-off in Casuarina equisetifolia (Poletto et al. 2015). To our knowledge, this is the first report of F. lacertarum causing rot disease in $N$. cochonellifera worldwide.

\section{Compliance with ethical standards}

Conflict of interest All the authors declare no competing financial interest.

\section{References}

Leslie JF, Summerell BA (2006) The fusarium laboratory manual. In: Blackwell publishing. USA, Hoboken

O’Donnell K, Sutton DA, Rinaldi MG, Gueidan C, Crous PW, Geiser DM (2009) J Clin Microbiol 47:3851-3861

Poletto T, Maciel CG, Muniz MFB, Blume E, Harakawa R, Bagiotto C (2015) First report of Fusarium lacertarum causing damping-off in Casuarina equisetifolia in Brazil. Plant Dis 99:1040 